\title{
Some Reflections on the Problems of Human Rights Education in Africa*
}

\author{
By Richard N. Kiwanuka
}

The examination of the teaching of human rights in the Afro-Asian context raises a strange anachronism. In many ways, countries in the Afro-Asian region (and in Latin America) are the areas in which the teaching of human rights and the dissemination of information on the subject are receiving little or scant specific attention.

- Faroq Hassan ${ }^{1}$

States parties to the present Charter shall have the duty to promote and ensure through teaching, education and publication, the respect of the rights and freedoms containd in the present Charter and to see to it that these freedoms and rights as well as corresponding obligations and duties are understood.

- Article 25, African Charter on Human and Peoples' Rights ${ }^{2}$

\section{Introduction}

This is an attempt, in a general sense, to share ideas about some of the most pressing problems confronting human rights education in the Third World, with specific reference to Africa, the veritable "laboratory " $^{3}$ of human rights.

The paper primarily addresses the problem from the point of view of university human rights education. This is in no way a statement on the relevance and importance of the other channels and levels of teaching and learning about human rights. Rather, it is dictated by the fact that presently in Africa, sadly, universities have a virtual monopoly

* This paper comes out of a wider study on Human Rights Education in Southern Africa kindly financially supported by Stichting European Human Rights Foundation of The Netherlands. An earlier version of the paper was presented at the Sixth Annual Human Rights Symposium and Research Conference at the Centre for the Study of Human Rights, Columbia University, New York, 11-14 June, 1985. The author is grateful to Associate Professor F.M. Auburn of the Law School, University of Western Australia for helpful comments on the draft. However, responsibility for the opinions expressed and errors made remains that of the author.

1 Professor Faroq Hassan in an Introduction to the Proposal on the Teaching of International Protection of Human Rights, in J.R. Friedman and L.S. Wiseberg, eds., Teaching Human Rights (Washington D.C.: INTERNET, 1981) p. 75.

2 OAU Doc. CAB/LEG/67/3/Rev. 5; (1982) ILM, 59; (1981) 27 Review of the International Commission of Jurists, 76. See also: Preamble to the Universal Declaration of Human Rights, G.A.Res. 217A, U.N. Doc. A/810 at 71 (1948).

3 Hassan, supra, n. 1. 
on formal human rights education. The problems arising out of this state of affairs, and the alternatives on hand, will be dealt with.

The basic issues, as we see them, can be divided into two broad categories. The first comprises problems of substance, that is to say, what should be taught or learned. The second is constituted by problems of resources - human and material. These two categories are, however, organically inter-linked.

\section{What Should be Taught?}

This problem faces and vexes many human rights educators worldwide. There have been numerous attempts to fix the goals of human rights education. For instance, in 1978, a meeting of Experts on Teaching about Human Rights in Secondary Schools held in Strasbourg emphasized that:

The purpose of education in Human Rights was to help pupils assume their responsibilities in the society in which they lived. They must learn certain things in order that, with this heritage, they must become actors and, even, more, creators in their lives. ${ }^{4}$

Three years later, the Council of Europe organised a seminar on Human Rights Education in Secondary Schools at Bergen, Norway. The seminar observed that "the Council of Europe insists on pluralistic democratic regimes". To support that objective then, "human rights education must be education for pluralism as well as education for democracy ". ${ }^{5}$

The message is clear. Human rights education must serve the goals and aspirations of society. It must be responsive to the needs of the people among whom it is dispensed or otherwise operated. Herein lies the justification for differing approaches to human rights education by different societies. ${ }^{6}$

At a UNESCO Consultation on the Teaching of International Law in Africa, Professor Austin from Harare, referred to the need to "address ourselves to setting an agenda of problems which are problems of Africa". He continued: "Otherwise we are in danger of continuing to think about problems which have been 'set for us' by writers and scholars elsewhere".?

4 Report of the Meeting of Experts on Teaching about Human Rights in Secondary Schools, Strasbourg, 6-8 December, 1978, p. 9, DEC/EGT (78) 45.

5 DEC 5/EGT (81) 71 p. 1.

6 See further: Reports of the Committee of Experts for the Promotion of Education and Information in the Field of Human Rights, (DH-ED) Doc. HE-ED (81) 16 (Council of Europe); UNESCO, Proceedings of the International Congress on the Teaching of Human Rights, Vienna, 12-16 September 1978, pp. 42-43; R.B. Bilder, 'Rethinking International Human Rights: Some Basic Questions', (1969) 2 Revue des Droits de l'Homme, 557.

7 R.H.F. Austin, 'The Role of Africa in the Development of International Law - the Contribution of A frican Regional Institutions to the Development of International Law, paper read at the UNESCO Consultation on the Teaching of International Law in Africa, Yaounde, Cameroun, December, 1983, SS-83/YAOUNDE/ No. 11 , p. 3. 
The problem Professor Austin was referring to was the teaching of human rights in Africa from a non-African perspective. It was the teaching of human rights in Africa in a way that was oblivious to African human rights problems and achievements. The majority of programmes do not reflect the people's problems, that is to say, hunger, squalor, destitution, illiteracy, disease, peace and the fragility of democracy.

Generally speaking, most of the existing human rights programmes in African universities are traditional. They are traditional in the sense that the approach is not distinguishable from that of the iniversities of the western world. They have hardly kept pace with developments on the continent. ${ }^{8}$ The emphasis is mainly on the international instruments of promotion and protection. From the municipal law point of view, attention is focused on the formal provisions of the law, which in many cases may be irrelevant to the situation. Keeping on the sure ground of international instruments and municipal positive law leads to an inability to come o terms with the underlying causes of the problems. A student graduates with a confused picture. He is theoretically well-grounded in a law or laws which may be unhelpful.

While he or she is still sorting him or herself out, a Bokassa, Nguema or an Amin marches onto the scene. Constitutions are literally torn up and dumped in military dustbins. Human rights are crudely banished from the realm of realisable goals to

8 The National University of Lesotho offers an elective unit on Human Rights to LL.B. students. Briefly, it is organised as follows:

Part 1: Principles and Norms of Human Rights

(a) Introduction: The Distinguishing Criteria of Institutions of Human Rights

(b) Fundamental Principles of Human Rights: Self-Determination

(c) Survey of the Positive International Law of Human Rights

(d) Economic, Social and Cultural Rights

(e) Civil and Political Rights

- Problems in the Application and Interpretation of Civil and Political Rights

- Analytical Examination of Civil and Political Rights

(f) Principles and Norms of Human Rights applicable in emergency situations

Part 2: International Institutions for the Protection of Human Rights

(a) Universal Institutions

(i) United Nations Organs: The principal institutions and other bodies founded under the Charter; Institutions and procedures founded on Conventions on Human Rights and fundamental freedoms

(ii) Specialized Agencies: ILO, UNESCO, UNHCR

(b) Regional Institutions for the Protection of Human Rights

(a) The Organisation of African Unity

(b) The Council of Europe

(c) The Organisation of American States

(d) The Socialist Countries and Human Rights

Part 3: Conclusion

- Towards a Specific International Human Rights Law: Basic Reading:

(a) Van Der Vyver: Seven Lectures on Human Rights

(b) David Owen: Human Rights

(c) H. Lauterpacht: International Law and Human Rights

Source: The National University of Lesotho Calender, 1984-1985, pp. 226-227

The University of Nairobi offers a course to LL.M. (I) students entitled: Human Rights and Self-Determination. Apart from added attention to "self-determination", the 1983-84 course outline was not markedly different to that of the National University of Lesotho, cited above. 
dangerous dreams. The scenario as it unfolds rudely and comprehensively confounds the products of straditional-approach human rights experts. It is nothing they are trained to deal with.

\section{The Uganda Example}

For his part, Amin took power on 25 January, 1971. Six days later, he abolished Parliament ${ }^{9}$ and joined in himself the powers of the Executive and the Legislature ${ }^{10}$ The same day, he dissolved all District, Municipal and Town Councils. ${ }^{11}$ Two days later, he passed a Decree providing for the supremacy, in cases of conflict and inconsistency, of his decress over any existing law, including the Constitution. ${ }^{12}$ Indeed the bull had marched into the human rights china shop.

The democratic edifice believed mandatory for this era, was brought crushing to the ground with the storke of a pen, preceded, of course, by the more decisive one of the barrel. Our human rights experts - lawyers etc., were left in an quandary, just like most other people. Many went to work and floated theories which attributed the confusion and ensuing carnage to lack of a parliament and freedom of association, ${ }^{13}$ lack of separation of powers, ${ }^{14}$ illiteracy in the army ${ }^{15}$ and executive, Amin's personality, ${ }^{16}$ and even to an act of God. ${ }^{17}$ All of these skirted the basic issues: why the nightmare and what to do? The intellectuals on the ground could not play any meaningful role in the struggle for democracy, of which Amin was only a chapter.

Ironically, the human rights provisions of the 1967 Republican Constitution were not tampered with by Amin. Chapter Three, which provided for basic rights and fundamental liberties, was almost a replica of the 1948 Universal Declaration of Human Rights. This demonstrated that it was perfectly possible to have extensive legal guarantees and

9 This was a one-party parliament. The civilian Government of Milton Obote had already abolished all opposition parties in 1969: The Penal (Unlawful Societies No. 2) Order, 1969 and Statutory Instrument No. 233 of 1969. See further: [1970] African Research Bulletin. 1728A, 1841B.

10 Legal Notice 1 of 1971.

11 Decree 2 of 1971.

12 Decree 3 of 1971.

13 Genuine participating democracy has eluded Uganda almost since independence. The controversial postAmin elections of 1980 did not lead to stability.

14 There has never been any real separation of powers in Uganda. For instance, judges are appointed by the Executive and have always been dismissed by the same at will and without reference to the constitutional Judicial Service Commission. The removal of Mr Justice Wambuzi as Chief Justice at the end of 1980, just a few days before elections, was one case in point.

15 It would be interesting to find out why this had consistently been the case from the colonial days to the beginning of 1986. See further: A Mazrui, Soldiers and Kinsmen in Uganda. 1975.

16 E.g. D. Martin, General Amin, 1975 pp. 199, 246-50. See generally: D. Gwyn, Idi Amin. 1977; T. and M. Melady, Idi Amin Dada: Hitler in Africa, 1977.

17 Drum (Nairobi), frequently replaced the name "Pearl of Arica", which Churchill had given to Uganda on his visit there with: "The Land that God Forgot". 
massive violations of human rights. The two, though inconsistent, are not mutally exclusive. ${ }^{18}$

Military dictators, however, do not have a patent on massive human rights violations. To human rights education this can only mean that there cannot be any easy answers.

\section{The Ecology of Human Rights Education and its Effect}

Teaching human rights or promoting its education in Africa, and indeed in many third world countries, is a trying experience. Educators are frequently forced to strike a fine balance between opposing forces and interests, which may include self-preservation. How do they fare?

Educators working under viciously dictatorial regimes show a tendency of emphasizing the international dimensions of human rights. They also stress non-political rights, to wit, economic, social and cultural rights. However, analysis cannot go very deep as even those rights lead back to the politically sensitive civil and political liberties. However, there are others who content themselves with survival under the prevailing circumstances. They pre-occupy themselves with finding a niche in which to survive, pleading responsibilities to their families and careers. To beat the odds of insecurity and inflation, they are happy to be government advisers, consultants, directors and petty-businessmen. They would do nothing to rock the boat. On the contrary, they eschew anything sensitive, steering clear of the real issues. Sometimes, they even assist, knowingly or carelessly, in the distortion of the truth. Many academics have lent their names, prestige and authority to misleading reports and white-washing commissions.

The first response by human rights educators is timorous and intellectually escapist. The degree of caution is directly proportional to the viciousness of the governors. The second response is ostrich-like. It is, at the same time, opportunistic and has the potential of leading to intellectual dishonesty at the slightest temptation. The difference between the two is not always clear-cut. In both cases, though, there is a dichotomization of theory and practice. In differing degrees, this is counter-productive. It stymies attempts in developing countries meaningfully to contribute to the science of human rights by developing theories based on practice.

18 G.W. Kanyeihamba, Constitutional Law and Government in Uganda. 1975, p. 436: "It is ... not the law as written down but rather its application that matters to the community." One of Amin's first functions as Head of State was to abolish the State of Emergency, declared by his predecessor in 1966, and free all political detainees. 


\section{The Debate on Ideology}

Professor Richard Claude aptly observed that: "[h]owever objective, no student of comparative human rights can ignore the ideological dimensions of his research " ${ }^{19}$ Human rights education, it is submitted, is, as a general rule ideologically weighted. This is a rule that would admit of few exceptions in a socially and politically conscious human rights programme. ${ }^{20}$ The ideological base could be easy to discern, it could also be subtle. Those of us who are convinced that ideologically based education is not necessary or is even dangerous, are unwittingly, in agreement with this proposition. ${ }^{21}$ It is one way of recording satisfaction with the status quo.

What then is the ideological or philosophical basis for human rights curricula in developing countries? This is not an easy question. Certainly, there is no agreement amongst the educators and the issue may not easily be settled merely by examining the syllabi. Perhaps then we can appreciate the dilemma which Andrew Drzemczewski faced when preparing an outline for students at the London School of Economics for the course on International Protection of Human Rights. Under the section dealing with ideological and philosophical foundations, he listed three topics: the liberal western traditions, the marxist approach and third world priorities.

As already observed, the approach in most African universities is not markedly different from that in the west. For most, the starting point is the Magna Carta, the American Declaration of Independence and similar documents and experiences. There is little wonder then, that human rights have been regarded by many as judaeo-christiar precepts primarily relevant for western societies. Unless the foundations of human rights can be argued and proved to lie within African societies themselves, what answer can we give to the tyrant who dismisses human rights demands as subversive "foreign ideologies"?

This traditional approach is largely a function of three closely related factors. ${ }^{22}$ Firstly, the apices of most of our education systems are still, de facto, in western countries. ${ }^{23}$ Secondly our "literature still tends to emanate from London, Paris, New York, the two Cambridges and similar centres". ${ }^{24}$ Thirdly, owing to the current imbalance in interna-

19 R.P. Claude, 'Reliable Information: The Threshold Problem for Human Rights Research', (1977) 6 Human Rights, 169 at 172.

20 See e.g.: notes 4 and 5 supra.

21 An analogy to Pascal must be apposite here: "Se moquer de la philosophie, c'est vraiment philosopher." Pascal, Pensées, i.4.

22 Indeed it could be argued that all three are but a manifestation of the same problem, namely the position Africa currently occupies in the world order.

23 Most African specialists obtain their advanced training from overseas. However, in some countries, such as those in southern Africa, influence on the education system from abroad is felt at much lower stages through the system of external examinations at secondary school level.

24 R.H.F. Austin, 'The Role of Africa in the Development of International Law - The Contribution of African Regional Institutions to the Development of International Law', paper read at the UNESCO Consultation on the Teaching of International Law in Africa, Yaounde, Cameroun, December 1983, SS-83/YAOUNDE/ No. 11, p. 3 . 
tional economic relations, there is a tendency for scholars, politicians and planners to look to the industrialised western world for solutions to problems of underdevelopment. ${ }^{25}$ Sometimes though, this choice is not made entirely voluntarily. Where donors are determined to "remake Africa in their own image" ${ }^{26}$ enormous pressure is brought to bear on all actors to discharge their roles in a particular way.

It is fair to state, therefore, that the philosophical and ideological base for human rights education in many developing countries is the same as that of the countries in the metropolis. This conclusion is subtly evident in some countries, an glaringly apparent in others. Let us illustrate this with an example from East Africa. In 1982, the University of Nairobi was the scene of some very lively debates between marxist and non-marxist faculty and students. However, the government intervened to deliver an unequivocal "no-no" to the marxist camp. Many professors of the said camp were detained and later lost their chairs and appointments. The Standard, a Nairobi daily, ran a front page story on June 15, 1982, under the title: "Njonjo raps Marxists". In the story, the Honourable Minister (as he then was), was quoted as having asked the Minister for Higher Education

... to ensure that Marxist-oriented lecturers are not paid during the period the students are away [after riots]... . He also asked the Minister to scrutinize the academic certificates of the lecturers and where they were educated. "Some of them were trained in communist countries and are not qualified to teach our children". He said. ${ }^{27}$

The then No. 3 man in Kenyan politics was determined to ensure a particular direction for the education system and nation. For, in the words of Alexander Pope:

'This Education forms the common mind. Just as the twig is bent, the tree is inclined. ${ }^{28}$

\section{Development of a Foundation and Development as a Foundation}

Recent years have witnessed a slow but gradual movement towards the development of a set of priorities, which are sensitive to extant problems, for human rights education in

25 See generally: M. Bedjaoui, Towards a New International Economic Order. 1979.

26 U. Wasserman, 'The Economic Situation in Africa', (1984) 18 Journal of World Trade Law. 555 at 562; See further: Comments by Jeane Kirkpatrick, [April 1986] 4 World Development Forum. 3 (The Hunger Project, Washington D.C.).

27 Seealso: The Daily Nation (Nairobi), June 14, 1982, p. 1; [1982] Africa Diary. 11011, 11066, 11146, 11170-71 (New Delhi). However, not atypical of the confusion and ambivalence in underdeveloped countries, while Kenyan Marxist academia was being lambasted, the Kenyan Ambassador to the Kremlin, H.E. Mr E.C. arap Lang'at was reassuring Kenyan students in the Soviet Union:

"That the Kenya Public Service Commission gave jobs purely on merit and proper qualification for posts irrespective of where one has studied. [He also] dispelled the fear that those who studied in Eastern Europe were discriminated against in employment."

The Standard (Nairobi), June 15, 1982, p. 3.

28 Alexander Pope, Moral Essays, Epistle 1. To Lord Cobham (1733) 1.149. John Dryden, Hind and the Panther (1687) Part 1, 1.389:

By education most have been misled;

So they believe, because they so were bred.

The priest continues what the nurse began,

And thus the child imposes on the man. 
developing countries. This would be aided by the development of the right to development. ${ }^{29}$ The recent developments represent an intellectual reaction to the morass of economic stagnation, social deprivation and political chaos, pervasive in the third world. It is also a reaction to the neglect, by international human rights legal scholarship, of these realities. In the words of Phillip Alston:

It is not coincidental that the most underdeveloped part of human rights law is also that part which has been the subject of the least research and teaching. In practice, the fundamental principle which holds that all human rights are interdependent and indivisible is belied by the remarkable extent to which the concept of economic, social and cultural rights has been neglected..$^{30}$

These recent developments are a continuation of a journey which has such milestones as the recognition in international law of the principles of anti-colonialism, self-determination (which includes the principles affecting wars of national liberation), ${ }^{31}$ and the condemnation of racism, in general, and apartheid, in particular.

There is every incentive, therefore, to approach human rights education in Africa from the point of view of solving the human rights problems of the continent. Without much doubt it would be apparent that the centre of these problems is the massive underdevelopment of the continent. Development could, therefore, easily form the core of the foundation for human rights education in Africa. We would endorse Ballah Conteh's suggestion that:

In order to avoid providing illusory answers to the numerous problems of development, human rights teaching must reformulate in a more objective manner the needs of African countries, the attainment of their national objectives and the policies conducive to the realisation of those objectives. This implies that we should develop a human rights curriculum responsive to the various African societies' own ideals about the direction of progress or modernisation which they want. ${ }^{32}$

This approach received a boost with the adoption of the African Charter on Human and Peoples' Rights ${ }^{33}$ by the OAU Assembly of Heads of State and Government at their 18th Ordinary Session in Nairobi at the end of June 1981. The Charter was the first international human rights instrument to provide for the right to development. Article 22 stated:

29 See e.g.: Keba M'Baye "Le Droit de Dévéloppement Comme un Droit de l'Homme'“, (1972) 5 Nos. 2 \& 3 Revue des Droits de l'Homme, 505-534; Draft Declaration on the Right to Development, U.N. Doc. E/CN.4/1985/11 (1985).

30 P. Alston, 'Researching and Teaching the new Directions in Human Rights", in A. Eide and M. Thee, eds., Frontiers of Human Rights Education (Oslo: Universitetsforlaget, 1983), p. 15 at 16.

31 See e.g.: James E. Bond, 'Article 1 of Amended Draft Protocol 1 to the 1949 Geneva Conventions: The Coming of Age of the Guerillar, (1975) 32 Washington and Lee Law Review. 65-78; R.C. Pangalangan and E.H. Aguiling, 'The Privileged Status of National Liberation Movements Under International Law; (1983) 58 Philippine Law Journal, 44-65.

32 M. Ballah Conteh, 'Human Rights Teaching in Africa: The Socio-Economic and Cultural Context 4 , in Eide and Thee supra n. 30, p. 53 at 57.

33 Supra, n. 2. 
1. All peoples shall have the right to their economic, social and cultural development with due regard to their freedom and identity and in the equal enjoyment of the common heritage of manking.

2. States shall have the duty, individually or collectively, to ensure the exercise of the right to development.

The right to development is not, however, sufficiently well developed. There are many who believe that the right is nothing more than a reflection of the law de lege ferenda and should perhaps stay that way. ${ }^{34}$ The onus is upon the human rights educators and other specialists to concretise the right to development. There is a need to clarify or redefine the problem and proceed to solutions which combine theory and practice. International human rights standards could be studied from this viewpoint. As José Diokno opined:

If research delves deep into a developing nation's language and literature, oral or written, and into its art, traditions, culture and values, it will, if done properly, discover the indigenous roots of the peoples' native human rights concepts. If human rights teaching then interprets the rights set out in the Universal Declarations in terms of these native concepts, points out how such concepts may differ in content, emphasis or priority from the Universal Declaration, and explains the differences which will, in most cases, have resulted from responses to different problems or from the different level of development which was arrested by the advent of colonialism, human rights education would promote national identity, lead to rejection of dependency on developed countries, and motivate more arduous, self-reliant and autonomous development efforts. Instead of weakening developing nations' demands for a new international economic order, human rights teaching and research could strengthen them. ${ }^{35}$

The progress of the right to development and the "new" approach to human rights education are facing a number of hurdles. Both face lack of adequate comprehension, confusion and sometimes even resistance at home and abroad. These problems are thwarting the recognition of a fully-fledged third world human rights philosophy ranking pari passu with western and other philosophies. To these problems we now turn.

\section{Human and Material Resources}

Resources at the disposal of people in developing countries have a direct impact on the nature and quality of their education. To begin with, most human rights educators in Africa are not formally adequately trained for third world human rights problems. As already observed, educational institutions in the developed world continue to play a key role in the preparation of African man power. African educational institutions are still in the process of development, ${ }^{36}$ just like all other sectors of social and economic life.

34 See e.g.: J. Donnelly, In Search of the Unicorn: The Jurisprudence and Politics of the Right to Development,, (1985) 15 California Western International Law Journal. 47305-9; W. Levi, 'Are Developing States More Equal Than Others?, (1978) 32 Yearbook of World Affairs. 286-302.

35 J.W. Diokno, 'Human Rights Teaching and Research in the Context of Development: The East-West and North-South Dimensions, in Eide and Thee, supra, n.30, p.35 at 37.

36 Conteh, supra, n.32 at 56. 
The low level of adjustment of educational institutions in Africa can be historically explained. The colonial masters left many of their former-colonies with weak education systems. The level of development of the systems hardly corresponded with the length of the period of colonial rule. This was not accidental. In the case of Lesotho, for example, we get a clear indication of the goals of British policy in a Report of the Resident Commissioner for 1898-1899:

... To others who urge higher education of the natives, it may be pointed out that to educate them above labour would be a great mistake. Primarily, the native labour industry supplies a dominion want, and secondarily it tends to fertilise native territories with cash which is at once diffused for English goods. ${ }^{37}$

It was not surprising, therefore, that it was the Christian missionaries who pioneered in the field of education in most countries of Black Africa. However, this also had its own inherent problems. Most of the missionaries came from middle-class European backgrounds and were ill-prepared for the African experience. They were armed only with their faith, zealousness and, perhaps their feeling superiority. The early missionaries also imported to Africa their inter-denominational rivalries. This not only confused their converts but, in many cases, detrimentally and permanently transformed the nature of local politics. ${ }^{38}$

On the scene, these well-meaning missionaries found it well-high impossible to understand the indigenous ways of life. Since the people were radically different and were, objectively, at a lower stage of technical development, they were branded heathen and primitive. Their institutions, customs and traditions were made targets for denigration and destruction. Their leaders were believed to be "canny and watchful especially with strangers". ${ }^{39}$ The "natives" were thought to be oversuperstitous,${ }^{40}$ diabolical, ${ }^{41}$ purposeless $^{42}$ and in some instances, generally unenthusiastic. ${ }^{43}$

37 Quoted in the Introduction to the Kingdom of Lesotho Five Year Development Plan. 1980-1985, p. ii.

38 See further: A.G.G. Gingyera-Pinycwa, Issues in Pre-Independence Politics in Uganda (Kampala: East African Literature Bureau, 1976); H.B. Hansen, 'Church and State in Early Colonial Uganda', (1986) 85 African Affairs, 55-74 (London); D. Wadada Nabudere, Imperialism and Revolution in Uganda (London: Onyx Press, 1980) Chap.2.

39 Letter of Bishop Allard, Pietermaritzburg, 26 October, 1861, Reprinted in Recordsfrom Natal, Lesotho, the Orange Free State and Mozambique Concerning the History of the Catholic Church in Southern Africa (Roma, Lesotho, The Social Centre, n.d.) p.65.

40 Letter of Father Bompart, Pietermaritzburg, Ist April 1860, ibid, pp. 39-40.: "They are superstitious to the tip of their fingers".

41 Letter of Father Gerard, St Michael's, 10th June 1860, ibid., p. 47:

". . . Courage is needed to work among these men who have no idea of decency. . . Thanks be to God I am well aware of the craftiness and wiles of the Kafirs, for you know that duplicity and trickery is at the bottom of their character. The word "simplicity" exists neither in their language nor in their heart ..."

42 Supra, n.40.

43 Letter of Bishop Allard, supra, n. 39:

"(The Kafir) is not anxious to learn those doctrines that are not those of his nation. . . . He has very little enthusiasm."

However, many of these sweeping assumptions (and prejudices) were soon proved false, with a little patience and understanding. Two years after this statement, another missionary had a totally different view: 
In fairness, however, some credit is due to the early missionaries for exposing the people to skills of literacy and numeracy at a time when colonial governments seemed not to care. ${ }^{44}$ The missionaries usually started with centres for scripture studies which were later gradually expanded to secular studies. For example, the present National University of Lesotho occupies premises that originally were part of a monastery belonging to the Oblates. This was later developed into Pius XII College of higher learning. In 1964, the College was ceded to the Governments of Bechuanaland (now Botswana), Basutoland (now Lesotho), and Swaziland to form the core of the University of Bechuanaland, Basutoland and Swaziland. ${ }^{45}$

As a general practice, however, their efforts were mainly horizontal, as opposed to vertical. They concentrated on opening more and more missions so as to claim larger numbers of followers. This, coupled with official government neglect of education, meant that there was a practical ceiling on the education available to the people. In the case of southern Africa, this fitted in snugly with the general plan of the colonial government and industry. It made large number of Africans productively employable in South African mines and industries since they had the necessary basic skills.

Furthermore, domination by the missionaries of educational institutions meant that certain values and principles were promoted at the expense of those found in place. At the time of independence, most of the policy-makers had no points of reference, except those of their teachers and mentors. The dice had already been cast.

The lack of institutions of specialised training means that many African experts must journey abroad to receive the necessary training and qualifications. This would have many short-term advantages. The disadvantages are also apparent, especially in the social science field. Many of the graduates on returning home find it very difficult to apply their skills to the problems of underdevelopment. In the field of human rights education, scholars from developing countries find it difficult to receive more than a perfunctory exposure to the real problems of human rights in their countries. In theory, they would be expected to have gained the necessary expertise to address the real issues. In practice, this proves to be a very demanding proposition.

"The Basuto are very keen. I know of a boy about thirteen years of age who had much dealings with good catholics; not only did he want to become a catholic himself but in all the reunions where protestants attack our religion he takes up cudgels in our defence. His method is quite ingenious. Another Kafir was telling one day that the Catholic religion had become old and that was why the protestant religion had come to reform it. "The Catholic religion has become old! How can it be that the word of God should become old and need the word of man to reform it?" replied our knight errant."

Letter of Bishop Allard, Our lady Immaculate, Basutoland 6th November, 1862, supra, n.39 at 86.

See further; F. Laydevant, The Rights of Initiation in Basutoland (Transl. Rev. Graham Chadwick), unpublished Roma, Lesotho, 1978; 'Etude sur la Famille en Basutoland, (1931) 1 Journal de la Societé des Africanistes, 207.

44 See further: David Kimble, A Political History of Ghana: The Rise of Gold Coast Nationalism, 1850-1928 (London: OUP, 1971).

45 Later is became the University of Botswana, Lesotho and Swaziland. Now it has broken up into three separate national universities. 


\section{Research and Library Facilities}

Primary and secondary research in developing countries is a very slow, painful and frustrating exercise. Infrastructural facilities for research are acutely deficient. Records are improperly kept. Access is severely limited and sometimes encumbered by bureaucratic arrangements. Many governments insist on vetting research proposals, thereby lengthening the delays. In the rural areas respondents are frequently reluctant and suspicious. The assistance of chiefs and headmen could be required.

Public and institutional libraries are ill-equipped for human rights research. Human rights materials are scanty and superficial. The little that there may be does not deal with developing countries in a substantial manner. The following description of the law library of the University of Zimbabwe is not atypical:

When I returned to the University of Zimbabwe after independence I found a law library which was notable for the almost total absence of comparative materials on all aspects of law in Africa (with the exception of South Africa). It was even more notable for an almost entire lack of primary materials on international law. Its holdings were, as perhaps one might have expected, limited to the commentaries of learned authors - all English or American, and all written in English. ${ }^{46}$

The picture is as bad or even worse in many other African universities. In an answer to an enquiry regarding library and research facilities, one lecturer at the University of Swaziland Law School replied that the library was barely sufficient for teaching purposes and the few available books were competed for by students and teachers alike. ${ }^{47}$ Avenues for expressing ideas are severely constricted. The more read and established journals are in the developed world. Quite naturally, the publishers there would be more interested in issues that directly concern their readership. Those contributions that may concern developing countries, (and they are increasing in number) largely submitted by western scholars, are not, for financial reasons, widely read in Africa ${ }^{48}$ It is some sort of a no-win situation which can only be remedied by the strengthening of the African publication industry.

Exposure of African human rights ideas and concepts is severely impeded, especially on the continent itself. In Africa, the number of scholarly journals is very small. Many have closed down due to pressures of finances and sometimes manpower.

In the Eastern African region the following are no longer in print: African Review

46 Austin, supra, n.24 at 4; See generally: R.N. Kiwanuka, 'The Teaching of International Law in Southern Africa', (1984) 24 Indian Journal of International Law, 525-538.

47 Mr Ronald Nhlapo, 15 November, 1983.

48 Corrine Nyquist in 'Library Resources and Research Problems on Human Rights in Africar (a paper presented at a conference on International Human Rights: Dilemmas of Liberty and Development in Africa, May 1982, SUNY at Buffalo), outlines the problems of research on human rights in Africa from NorthAmerica. Ironically, from a library-research point of view, despite the problems she so ably discusses, it would be easier to conduct such research in North-America than on the continent itself. An updated version of the paper has been published in C.E. Welch Jnr. and R.I. Meltzer, eds., Human Rights and Development in Africa (Albany, N.Y.: SUNY Press, 1984). 
(Dar-es-Salaam), Makerere Law Journal (Kampala), and the East African Law Journal (Nairobi). The Eastern African Law Review (Dar-es-Salaam) has just reappeared after an absence of more than seven years. In the whole of the Eastern and Southern African region, excluding the Republic of South Africa, a region with more than twelve law schools, there are only a couple of law journals appearing regularly, viz., the Lesotho Law Journal and the Zimbabwe Law Journal (formerly Rhodesia Law Journal). The Zambia Law Journal still manages to appear although, one feels, with the greatest difficulty.

A meeting of African international lawyers organised in Lusaka in April 1986, launched the much awaited-for African Association of International Law (AILA). ${ }^{49}$ The main aim of the Association would be to foster development and application of international law to the present needs of African states. Its future plans include the publication of an African Yearbook of International Law.

One hopes the Association will make research and dissemination in the field of human rights one of its priority concerns.

Mention should also be made of the African Human Rights Research Association (AHRA), founded by the African participants at the 14th study session of the International Institute of Human Rights, Strasbourg, France, in July 1983. According to its Statement of Aims and Objectives:

AHRA is committed to offering wide and alternative conceptualizations and interpretations of the concept of Human Rights and the wideranging practices the concept seeks to reflect. AHRA is a network of individuals based in several countries in Africa, Europe and North America ... [AHRA intends] to contribute to the better understanding of the human rights situation in Africa and perhaps inform in the positive sense those better placed to affect the promotion and protection of human rights in Africa.

The Association seems gradually to be increasing in strength. It has on its credit, so far, more than twenty working papers and, soon, a human rights guide entitled: The International Law of Human Rights in Africa: Basic Documents and Annotated Bibliography will be published by Sitjhoff and Nijhoff of the Netherlands. ${ }^{51}$

\section{The Future}

The most immediate objective should be the reassessment of the content of human rights education with a view to aligning it with the political, social and economic realities of our

49 The current address of the Association is; C/o Dr T. Huaraka, Secretary-General, 34 Rue du Nant, 1207 Geneva, Switzerland. The other elected officers were: Judge T.O. Elias, President; Judge Keba M'Baye, Vice-President; Judge Mohammed Bedjaoui, Chief Editor of the Yearbook.

50 Address: 2 Assiniboine Road, Suite 622, Downsview, Ontario, Canada M3J ILl.

51 Letter from Mr M. Hamalengwa, Secretary-General, of July 3, 1986 to the present writer. See also: J Cobbah and M. Hamalengwa, 'The Human Rights Literature on Africa: A Bibliography، (1986) 8 No. 1 Human Rights Quarterly, 115-125. 
societies and peoples..$^{52}$ African Education Ministers meeting in Lagos in 1976 addressed themselves to the general but critical issue of goals and objectives of African education systems. Their very first recommendation was:

[T] hat the objectives and goals of educational systems be reconsidered in the light of changing economic, social and cultural needs of independent Africa, and especially in view of the declared policy of the new international economic order..$^{53}$

It is imperative that human rights educators have the correct perspective of the human rights problems they are dealing with. Presently, this can only be achieved with great pain. The manpower to lead the education struggle needs a lot of improvement. This "will require imagination as well as work and money". ${ }^{54}$ Furthermore, the "traditional patterns of study which suited a previous era of institutions of higher learning will have to be changed ". ${ }^{55}$

It has already been adequately stressed above that present African educational structures and strategies do not appropriately respond to our problems. While institutions of higher learning in the developed countries still provide the easy short-term solution to our manpower problems, we should consider that training merely as basic. The more important training must be back home with the actual problems. This is where imagination will be required. Due to lack of materials, the educator faces an uphill task of ascertaining the problem and looking for answers. It is also here that we see the traditional educational strategies and approaches falling to pieces. These assume that the educator is the citadel of knowledge and his students are but mere receptacles of the same. ${ }^{56}$ Well, in our situation the problem itself is not clear, let alone the solutions. Therefore our traditional teacher will have little to impart and even that might be inaccurate. There is then only one alternative. The educator will have to assume a lower profile and become a mere leader in the quest. The problem then will be investigated by the group working as a team with a leader. This approach is certainly more democratic and allows for a genuine clarification of the problem and a meaningful search for solutions. With this approach it becomes easier to liberate human rights education from the confines of classrooms and into village fora, or to use an East African term, barazas, and such informal arrangements which correspond to the situation of the majority of the

52 See further: Conteh, supra n.32; Hiroko Yamane, 'Development of Human Rights Teaching and Research in Asia: Toward a De-ideologization Through information', in Eide and Thee, supra. n.30 p. 45 at 50.

53 Recommendation No.1, Conference of Ministers of Education of African Member States held in Lagos, 1976, UNESCO, EDUCAFRICA, Dakar 1983, p.13; A meeting of Vice-Chancellors and Rectors of African Universities held in Addis Ababa, in February 1982 recommended, inter alia that "curricula throughout the educational system in Africa should be oriented towards meeting the socio-economic development needs of African states, and particularly the needs of rural communities which constitute the vast majority of African societies and the pillars of African economics«.: [1982-1983] Africa Contemporary Record. C25. The same sentiments were echoed by a conference of African Education and Economic Planning Ministers, held in Harare in July 1982: Ibid, C26.

54 Austin, supra, n.7 at 4.

55 Idem.

56 Paulo Freire, Pedagogy of the Oppressed (Penguin Books, 1972) Chap.2. 
people inhabiting the rural areas. This leads us to the issue of informal human rights education.

\section{Informal Human Rights Education}

It is a well established fact that the majority of people on the African continent are illiterate and stay in the villages leading uncomplicated subsistence lives. In many countries, it is these people who bear the brunt of the continent's human rights problems. A credible human rights programme should attempt to reach these people. They should be assisted to appreciate the objective forces that shape their existence and how best to transform their lives. In so assisting them, however, care must be exercised not to dictate to these people what their problems are and what the solutions should be. ${ }^{57}$ The role of the educator should be participatory. His or her objective should be to enable or empower the constituents democratically to articulate the problem and together to look for solutions. ${ }^{58}$

Research in the human rights educational value of traditional institutions has been insufficient and sometimes misleading. For example, consider the following conclusion of a study on the rites of initiation in Lesotho:

... [It] is certain that the obscene words and suggestive atmosphere of this institution have contributed greatly to the corruption of morals with all its consequences such as jealousies, hatred, murders, veneral diseases, etc.

Instead of being useful to native society, which wants to be instructed and civilized, the schools have become the chief obstacle to civilization and progress. They encourage and preserve superstitions and magic medicines, among which must be counted human flesh, the cause of ritual murders. It is above all in the schools that these murders are propounded and encouraged.

On the other hand this institution teaches scorn of women and hatred of white people..$^{59}$

The attitude of the missionaries was perhaps pardonable. The task facing us today, is to set the record straight and build a credible base for human rights research. We must investigate the value, in human rights education terms, of such institutions as circumci-

57 Bunker Roy, 'Development Goals and the Community', [1984 Nov/Dec] No.6 Development and Co-operation, 15 at 16 (Bonn):

"Why do we want community participation? Because we want better thinking human beings, we want people to start standing on their own feet, we want them to realise their strength and use it to achieve what development programmes are supposedly trying to do: to make communities self-reliant. And yet when we see this happening in front of our eyes, when we, in fact, see the Developed Man, we are mortally scared of him. Why? What does he look like? He is the person who answers back: he asks questions and points out flaws in the system. His economic status does not prevent him from naming the corrupt of ficials. He puts pressure and expects the system to respond by taking action. He does not care of his family is hurt in the process but stands for what is right and just in his eyes and which is not too different from the way we urban types look on the same issues. To be able to do this in a village where the pressures are real, intense, immediate and dangerous requires a lot of guts."

58 See generally: Paulo Freire, supra n.56.

59 F. Laydevant, The Rites of Initiation in Basutoland (Roma, Lesotho: The Social Centre, 1951) p. 53. 
sion schools, village councils, marriage instruction sessions, traditional courts, and the like. Tradition is also replete with many customs geared towards developing responsible individuals. These must be investigated ${ }^{60}$ Having done that, research must move to other areas of informal instruction such as religious channels, trade unions, the media, co-operatives and other organisations. This is not to neglect formal channels such as schools and universities. It is to correct the imbalance of attention. This imbalance neglected the channels of instruction which reach the majority of the people.

Professor Andrew Horn, working with a group of students from the National University of Lesotho, demonstrated how theatre, for instance, can be a powerful tool in community development. ${ }^{61}$ The group, using a variety of theatrical skills, gives life to a community problem (such as health, sanitation, crime, conservation, etc.) before a village audience in an outside arena. The villagers participate in a discussion of the issues raised by the performance and would on more than one occasion immediately resolve to take action to remedy a particular problem. Sometimes, by inviting government officers, the "villagers' concerns are [not only] transmitted directly to the official bureaucracy, but . . p popular theatre [can] be demonstrated as an effective alternative or adjunct to the more conservative, somewhat unimaginative and often authoritarian development methods already employed by government agencies $"{ }^{62}$

\section{Resources}

The future holds for us the herculean task of picking ourselves up by our own bootstraps. Most of the work will have to be done by us. In this connection, it is imperative to investigate avenues for increased co-operation amongst African human rights specialists, professionals, students and institutions. This co-operation could take the form of regular exchanges. It is ironic that it is easier to find sabbatical placement for faculty in American and European than in African universities. This is conditioned by several factors which include financing, language, resources, communication and research interests.

Co-operation could also take the form of formal and informal meetings, exchange of external examiners, and of teaching and research materials. Furthermore, a human rights newsletter could serve as an important informal link amongst the different individuals active in the African human rights field, on the continent and elsewhere. It would keep all those concerned abreast of developments and on-going activities.

In the longer-term we could focus on the creation of a continental organisation of human rights specialists and other professionals, perhaps under the aegis of the African Interna-

60 See Diokno, Supra, n. 35.

61 A Horn, 'Public Health, Public Theatre: A Report from Southern Africar (1984) 10 Nos.1 \& 2 Medicine in Society, 45-48.

62 Ibid at 47. 
tional Law Association. This would provide the organisational base on which to consolidate and improve our gains.

Lastly, serious thought should be given to filling the void of publication outlets. The problem of exposure of ideas must be tackled urgently. Africa-based publications could greatly improve the available teaching materials. Of course, one hopes that they would not be prohibitively expensive.

\section{Conclusion}

In the foregoing pages, we have attempted to discuss some of the major problems facing human rights education in Africa. Some of these problems directly relate to the content or substance of the education. The complaint we made was that, in many cases, formal human rights education fails to correspond to the actual problems facing the African peoples. The other set of problems deals with the available resources. Under this heading, we discussed the inadequacy of material and human resources.

The burden of solving these problems lies squarely on the shoulders of African human rights educators, leaders, professionals and other participants. Of course, any assistance which does not affect the substance or independence of the participants would be more than welcome. In order to discharge this burden, old methods and assumptions will have to be re-examined. They would have to give way to more appropriate approaches and techniques. In view of existing constraints, this task, which must not be shunned, will require a lot of imagination, dedication, sacrifice and industry. 


\title{
The Legal Underpinnings of the Indonesian Technocratic Military Government
}

\author{
By Eva Maria Schaarschmidt-Kohl
}

\begin{abstract}
Although the principle of "negara hukum" (rule of law) is laid down in the Indonesian Constitution of 1945 it has been discredited under Sukarno's "old order" (being regarded as an element of the colonial heritage). With the establishement of Suharto's nnew order" in 1965/66, there have been efforts at legitimizing the now ruling technocratic military government. For both, Suharto's seizing of power as well as establishing his "new order" his government tried to construct a framework of legality, while in reality his soldiers and other government-mobilized forces (e. g. muslim youth gangs) persecuted, killed or detained thousands of people for being communists or alleged communists. In constructing this kind of legality the "new order" could make use of the colonial legislation which was still partly valid. Since then there have been successive acts of legislation, all aiming at securing this law-and-order rule based on oppression and the use of force. While the government propagated free elections political parties (as well as trade unions and other institutions) have been curbed, remaining political parties (and trade unions) having been forced to merge and forbidden to establish branches below district level. In respect of social movements similar laws have already been passed subjecting ever wider parts of society to government control. Since it is not possible to have laws scrutinized as to their constitutionality, there is no judicial recourse against unjust laws, exposing the individual to a nearly all-pervading power - a power based on law.
\end{abstract}

\section{Some Reflections on the Problems of Human Rights Education in Africa}

\section{By Richard N. Kiwanuka}

The paper seeks to deal with the major problems facing human rights education in Africa. In the author's view, these fall into two broad categories: substance and resources. A survey of a number of human rights curricula in Africa reveals that formal human rights education in Africa, which is monopolised by universities, hardly reflects the specific problems confronting the continent. Most of the education systems are, in any event, only gradually committing themselves to genuinely serving the needs of the recipients of the education they offer; they have tended to be elitist. Furthermore, conditions of underdevelopment have ensured Africa's dependence on institutions and personnel from the developed countries. This dependence postpones the development of an indigenous approach to human rights education.

The paper suggests that for African human rights educators not to be irrelevant, they must rededicate themselves to the aspirations of their people, especially in the fields of 
democracy and development. Increased co-operation amongst African educators and institutions should alleviate some of the material constraints. Further, other alternative methods of imparting human rights education should be canvassed. There are many informal channels which could be utilized to reach larger sections of the populations. In short, African human rights education has to seek some form of autonomy as well as efficacy. This will call for imagination and dedication. 